Journal of Health Science
(Jurnal Ilmu Kesehatan)
$\frac{\text { https://www.ejournalwiraraja.com/index.php/JIK }}{2356-5284 \text { (Print) } \mid 2356-5543 \text { (online) }}$

\title{
Anemia berhubungan dengan Perdarahan Post Partum
}

\author{
Zakiyah Yasin', Mujib Hannan², Erlyn Wahyuni ${ }^{3}$ \\ ${ }^{1,2}$ Fakultas Ilmu Kesehatan, Universitas Wiraraja \\ 1zakiyahfik@wiraraja.ac.id*,mujib@wiraraja.ac.id, erlyn@gmail.com \\ *Coresponding Author
}

\begin{tabular}{|c|c|}
\hline Informasi artikel & \multirow{2}{*}{$\begin{array}{l}\text { ABSTRAK } \\
\text { Ibu hamil yang mengalami anemia dan tidak tertangani hingga akhir }\end{array}$} \\
\hline Sejarah artikel: & \\
\hline Received:30-04-2021 & \multirow{19}{*}{ 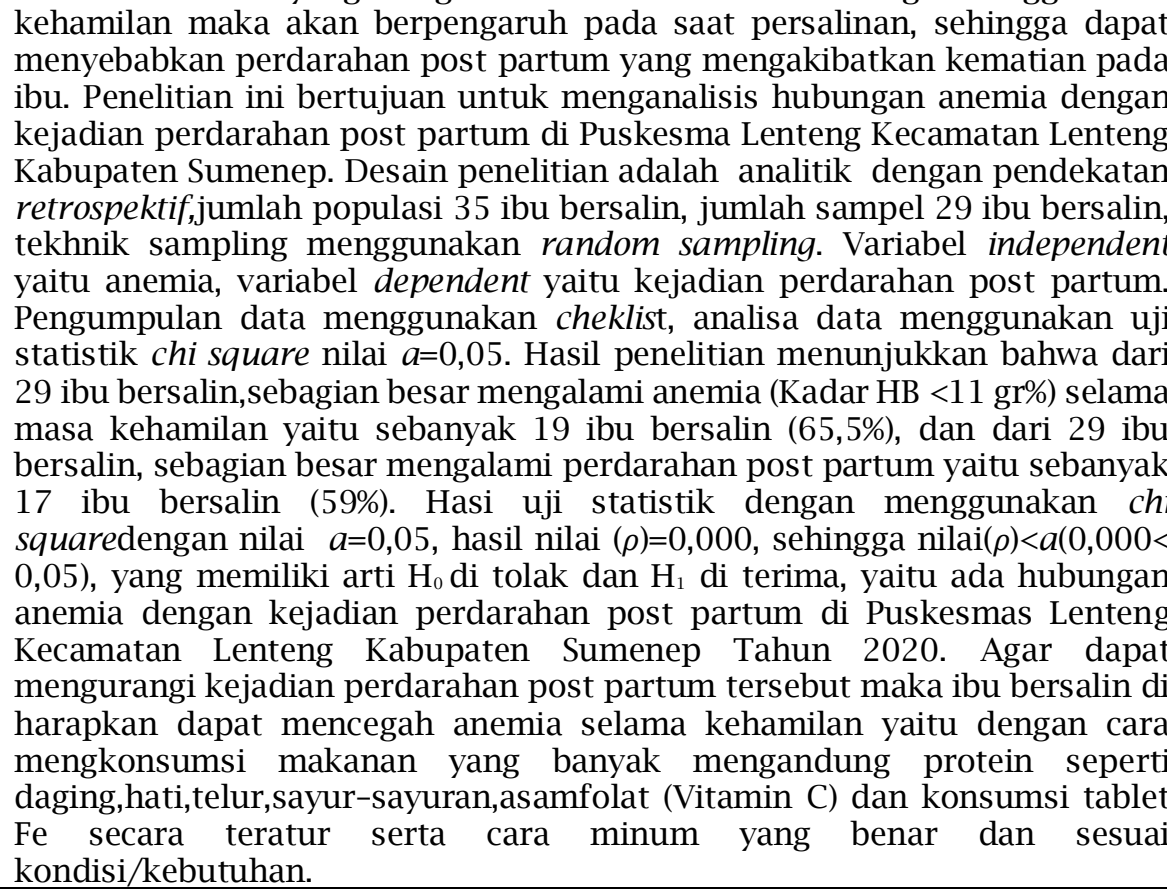 } \\
\hline $\mathrm{R}$ & \\
\hline 2021 & \\
\hline Kat: & \\
\hline Allemula & \\
\hline & \\
\hline & \\
\hline & \\
\hline & \\
\hline & \\
\hline & \\
\hline & \\
\hline & \\
\hline & \\
\hline & \\
\hline & \\
\hline & \\
\hline & \\
\hline & \\
\hline & \\
\hline
\end{tabular}

Key word:

Anemia

Bleeding events

Post Partum

\section{ABSTRACT} of pregnancy will have an effect at the time of delivery, so that it can cause post partum hemorrhage which results in death in the mother. This study aims to analyze the relationship between anemia and the incidence of post partum hemorrhage in Puskesmas Lenteng, Lenteng District, Sumenep Regency.The study design was analytic with a retrospective approach, the total population was 35 mothers, the total sample was 29 mothers, the sampling technique used random sampling. The independent variable is anemia, the dependent variable is the incidence of post partum hemorrhage. Collecting data using a checklist, data analysis using the chi square statistical test, the value of $\mathrm{a}=0.05$. The results showed that of the 29 women who gave birth, most of them experienced anemia (HB level $<11 \mathrm{~g} \%$ ) during pregnancy, as many as 19 mothers gave birth (65.5\%), and of the 29 mothers gave birth, most of them experienced post partum hemorrhage as much as 17 mothers gave birth (59\%). The result of statistical tests using chi square with a value of $\mathrm{a}=0.05$, the resulting value $(\rho)=0.000$, so that the value $(\rho)<\mathrm{a}(0.000<0.05)$, which means that $\mathrm{H} 0$ is rejected and $\mathrm{H} 1$ is accepted, i.e. the relationship between anemia and the incidence of post partum hemorrhage at the Lenteng Public Health Center, Lenteng District, Sumenep Regency in 2020. In order to reduce the incidence of post partum hemorrhage, it is hoped that the mother in labor can prevent anemia during pregnancy, namely by consuming foods 
that contain lots of protein such as meat, liver, eggs, vegetables, folic acid (Vitamin C) and consumption of Fe tablets regularly and how to drink properly and according to conditions / needs.

\section{PENDAHULUAN}

Setiap persalinan mempunyai hubungan dengan perdarahan, karena semua persalinan baik pervaginam ataupun perabdominal (section cesarean) selalu disertai perdarahan. Pada persalinan pervaginam perdarahan dapat terjadi sebelum, selama ataupun sesudah persalinan. Suatu perdarahan dikatakan fisiologis apabila hilangnya darah tidak melebihi 500 cc pada persalinan pervaginam dan tidak lebih dari 1000 cc pada sectioncesarea (Indriyani et al., 2020). Perlu diingat bahwa perdarahan yang terlihat pada waktu persalinan sebenarnya hanyalah setengah dari perdarahan yang sebenarnya. Perdarahan post partum merupakan salah satu masalah penting karena berhubungan dengan kesehatan ibu yang dapat menyebabkan kematian. Walaupun angka kematian maternal telah menurun dari tahun ketahun dengan adanya pemeriksaan dan perawatan kehamilan, persalinan di rumah sakit serta adanya fasilitast ransfusi darah, namun perdarahan masih tetap merupakan faktor utama dalam kematian ibu (Indriyani \& Suprayitno, 2017).

Menurut laporan WHO (2014) kematian ibu di dunia disebabkan oleh perdarahan sebesar 30,3\%, komplikasi persalinan 15,3\%, infeksi 16,5\%, aborsi yang tidak aman 10,8\%, tekanan darah tinggi saat kehamilan 27,1\%, Angka kematian ibu (AKI) di Indonesia masih sangat tinggi menurut Survey Demografi dan Kesehatan Indonesia angka kematian ibu adalah 305 per 1.000 kelahiran hidup (SDKI, 2019). Sedangkan di Jawa Timur tahun 2019 penyebab kematian ibu terbesar adalah karena perdarahan dan infeksi (DepkesRI, 2019).

Penyebab umum terjadinya perdarahan post partum adalah keadaan umum ibu yang lemah karena anemia, multiparitas, pasca tindakan oprasi, Distensi uterus berlebih, kelelahan ibu, trauma persalinan, dengan gangguan kontraksi (Mochtar, 2005). Sedangkan menurut Manuaba (2012) perdarahan post partum dapat disebabkan oleh atonia uteri, inversion uteri, robekan jalan lahir, retensioplasenta dan sisa plasenta. Menurut data di Puskesmas Lenteng, Kematian ibu bersalin/kematian maternal pada tahun 2019 kosong atau tidak ada.
Jumlah total persalinan di Tahun 2019 yamg mengalami penyulit atau beresiko berjumlah 35 orang. Jumlah Ibu hamil yang melakukan pemeriksaan atau ANC di Puskesmas Lenteng sebanyak 94 orang.

Dalam menanggulangi masalah di atas maka upaya yang dapat dilakukan untuk mencegah terjadinya perdarahan post partum dan segala dampak yang mungkin terjadi tidak hanya dilakukan pada saat bersalin tetapi sejak masa kehamilan dengan melakukan pemeriksaan ante natal care secara teratur di tempat pelayanan kesehatan (minimal $4 \mathrm{x}$ selama masa kehamilan) ,bersalin di rumah sakit yang mempunyai sarana dan prasarana yang lebih lengkap atau memiliki bank darah, konsumsi tablet fe selama masa kehamilan, penerapan asuhan persalinan normal sangat penting dalam mencegah komplikasi persalinan termasuk perdarahan post partum primer yaitu dengan pelaksanaan managemen aktif kala III dengan baik dan benar, penting juga untuk mencegah "Empat Terlalu" yaitu terlalu muda (16 tahun), terlalu tua ( $>35$ tahun) usia ibu untuk memutuskan hamil, terlalu sering melahirkan dan terlalu dekat jarak kehamilan/persalinan (SDKI 2012 periode Agustus 2013 ). Tujuan penelitian ini adalah Menganalisa hubungan anemia dengan kejadian perdarahan post partum di Puskesmas Lenteng Kecamatan Lenteng Kabupaten Sumenep.

\section{METODE PENELITIAN}

Dalam penelitian ini penulis menggunakan metode penelitian analitic correlational. Menurut Nursalam (2013). Jenis penelitian korelasional adalah penelitian yang mengkaji hubungan antara variable untuk mencari, menjelaskan, suatuhubungan, memperkirakan, dan menguji berdasarkan teori yang ada.Pendekatan yang digunakan adalah dengan studi retrospektif yaitu cass control. Populasi pada penelitian ini adalah semua ibu bersalin di Puskesmas Lenteng Kecamatan Lenteng Kabupaten Sumenep Tahun 2020 sebanyak 35 responden. Sedangkan jumlah sampel sebagaimana populasi dalam penelitian ini sebanyak 29 responden. 
Instrument yang digunakan pada penelitian ini adalah cheklist, baik variabel independen maupun variabel dependen.

Dalam menganalisis hubungan yang terjadi menggunakan uji statistik chi-squer yaitu pengujian apabila didapatkan penelitian dua variabel, masing-masing variable menggunakan skala nominal dengan tingkat kemaknaan 0,05 dimana $\alpha<0,05$ maka ada hubungan antara Anemia selama masa kehamilan dengan perdarahan post partum, sedangkan $\alpha>0,05$ maka tidak ada hubungan anemia selama kehamilan dengan kejadian perdarahan post partum.

\section{HASIL DAN PEMBAHASAN}

1. Karasteristik Responden Berdasarkan Usia

Tabel 1. Distribusi Frekuensi Berdasarkan Usia Responden

\begin{tabular}{cccc} 
No & Usia & Jumlah & Presentase \\
\hline $\mathbf{1}$ & $17-22$ & 13 & 44,8 \\
\hline $\mathbf{2}$ & $23-28$ & 6 & 20,7 \\
\hline $\mathbf{3}$ & $>29$ & 10 & 34,5 \\
\hline \multicolumn{2}{r}{ Total } & 29 & 100 \\
\hline
\end{tabular}

Sumber : Data Sekunder penelitian pada tahun 2020

Berdasarkan tabel 1 menunjukkan bahwa dari 29 responden di Puskesmas Lenteng Kecamatan Lenteng Kabupaten Sumenep Tahu 2020 sebagian besar yaitu sebanyak 13 responden (44,8\%) berumur antara 17- 22 tahun.

2. Karasteristik Responden Berdasarkan Pendidikan

Tabel 2. Distribusi Frekuensi Berdasarkan Pendidikan Responden

\begin{tabular}{cccc}
\hline No & Pendidikan & Jumlah & (\%) \\
\hline $\mathbf{1}$ & SD & 5 & 17 \\
\hline $\mathbf{2}$ & SMP & 14 & 48,5 \\
\hline $\mathbf{3}$ & SMA & 7 & 24 \\
\hline $\mathbf{4}$ & PT & 3 & 10,5 \\
\hline & Total & 29 & 100
\end{tabular}

Sumber : Data Sekunder penelitian pada tahun 2020

Berdasarkan tabel 2 menunjukkan bahwa dari 29 responden di Puskesmas Lenteng Kecamatan Lenteng Kabupaten Sumenep Tahun 2020 sebagian besar yaitu sebanyak 14 responden $(48,5 \%)$ berpendidikan SMP.

3. Karasteristik Responden Berdasarkan Pekerjaan

Tabel 3 Tabel Distribusi Frekuensi Berdasarkan Pekerjaan Responden

\begin{tabular}{cccc}
\hline No & Pekerjaan & Jumlah & (\%) \\
\hline $\mathbf{1}$ & Petani & 13 & 44,8 \\
\hline $\mathbf{2}$ & $\begin{array}{c}\text { Swasta/ } \\
\text { Wiraswasta }\end{array}$ & 9 & 31 \\
\hline $\mathbf{3}$ & $\begin{array}{c}\text { TidakBekerj } \\
\text { a/ IRT }\end{array}$ & 7 & 24,2 \\
\hline & Total & 29 & 100 \\
\hline
\end{tabular}

Sumber : Data Sekunder penelitian pada tahun 2020

Berdasarkan tabel 3 menunjukkan bahwa dari 29 responden di Puskesma Lenteng Kecamatan Lenteng Kabupaten Sumenep Tahun 2020 hampir setengahnya yaitu sebanyak 13 responden $(44,8 \%)$ pekerjaaannya adalah sebagai petani.

4. Anemia

Tabel 4 Tabel Distribusi Frekuensi Responden Berdasarkan Anemia

\begin{tabular}{cccc}
\hline No & Kategori & Jumlah & (\%) \\
\hline $\mathbf{1}$ & Anemia & 19 & 65,5 \\
\hline $\mathbf{2}$ & Tidak & 10 & 34,5 \\
& Anemia & & \\
\hline & Total & 29 & 100 \\
\hline
\end{tabular}

Sumber : Data Sekunder penelitian pada tahun 2020

Berdasarkan tabel 4 menunjukkan bahwa dari 29 responden di Puskesmas Kecamatan Lenteng Kabupaten Sumenep Tahun 2020 sebagian besar yaitu sebanyak 19 responden $(65,5 \%)$ mengalami anemia selama masa kehamilannya.

5. Distribusi Kejadian Perdarahan Post Partum

Tabel 5 Tabel Distribusi Frekuensi Responden Berdasarkan Perdarahan Post Partum

\begin{tabular}{cccc}
\hline No & $\begin{array}{c}\text { Kejadian } \\
\text { Perdarahan }\end{array}$ & Jumlah & (\%) \\
\hline $\mathbf{1}$ & Perdarahan & 17 & 59 \\
\hline $\mathbf{2}$ & $\begin{array}{c}\text { Tidak } \\
\text { Perdarahan }\end{array}$ & 12 & 41 \\
\hline & Total & 29 & 100
\end{tabular}

Sumber : Data Sekunder penelitian pada tahun 2020

Berdasarkan tabel 5 menunjukkan bahwa dari 29 responden di Puskesmas Lenteng Kecamatan Lenteng Kabupaten Sumenep Tahun 2020 sebagian besar yaitu sebanyak 17 responden (59\%) mengalami perdarahan post partum.

6. Tabulasi Silang Anemia dengan Kejadian Perdarahan Post Partum

Tabel 6 Tabel Tabulasi Silang Anemia dengan Kejadian Perdarahan Post Partum 


\begin{tabular}{cccccccc}
\hline \multirow{2}{*}{$\begin{array}{l}\text { N } \\
\mathbf{o}\end{array}$} & \multirow{2}{*}{ Anemia } & \multicolumn{4}{c}{ Perdarahan } & \multicolumn{2}{c}{ Total } \\
\cline { 3 - 7 } & & \multicolumn{2}{c}{ Perdarahan } & \multicolumn{2}{c}{ Tidak } & \multicolumn{1}{c}{} \\
\cline { 3 - 7 } $\mathbf{1}$ & Anemia & 17 & $\%$ & $\mathrm{~N}$ & $\%$ & $\mathrm{~N}$ & $\%$ \\
\hline $\mathbf{2}$ & Tidak & 0 & 0 & 10 & 100 & 10 & 100 \\
\hline & Total & 17 & 58,5 & 12 & 41,5 & 29 & 100
\end{tabular}

Sumber : Data Sekunder penelitian pada tahun 2020

Berdasarkan tabel 6 menunjukkan bahwa dari 19 responden yang mengalami anemia selama masa kehamilan hampir seluruhnya yaitu sebanyak 17 responden $(94,5 \%)$ mengalami perdarahan post partum. Sedangkan dari 10 responden yang tidak mengalami anemia semasa kehamilan seluruhnya yaitu 10 responden (100\%) tidak ada yang mengalami perdarahan post partum.

Setelah di lakukan uji statistik menggunakan uji Chi Square didapatkan nilai probabilitynya $(p)=0,000$. Hal ini menunjukkan nilai probability $(p)$ kurang dari $\alpha(0,000<0,05)$ maka dapat memberikan arti bahwaH $_{0}$ di tolak dan $\mathrm{H}_{1} \mathrm{di}$ terimayaituadahubungan anemia dengan kejadian perdarahan post partum di Puskesmas Lenteng Kecamatan Lenteng Kabupaten Sumenep Tahun 2020.

\section{PEMBAHASAN}

\section{Anemia}

Berdasarkan hasil penelitian menunjukkan bahwa dari $29 \mathrm{ibu}$ bersalin di Puskesmas Lenteng Kecamatan Lenteng Kabupaten Sumenep Tahun 2020 sebagian besar yaitu sebanyak 19 ibu bersalin $(65,5 \%)$ mengalami anemia selama masa kehamilannya kehamilannya, sedangkan ibu bersalin yang tidak mengalami anemia sebanyak 10 ibu bersalin (34,5\%).

Anemia adalah kondisi dimana sel darah merah (eritrosit) menurun atau menurunnya hemoglobin, sehingga kapasitas daya angkut oksigen untuk kebutuhan organ-organ vital pada ibu dan janin menjadi berkurang (Tarwoto, 2017). Volume darah ibu hamil bertambah lebih kurang sampai 50\% yang menyebabkan konsentrasi sel darah merah mengalami penurunan.Bertambahnya sel darah merah masih kurang dibandingkan dengan bertambahnya plasma darah sehingga terjadi pengenceran darah. Perbandingan tersebut adalah plasma 30\%, seldarah $18 \%$ dan haemoglobin 19\%. Keadaan ini tidak normal bila konsentrasi turun terlalu rendah yang menyebabkan hemoglobin sampai<11 gr\%. Meningkatnya volume darah berarti meningkatkan pula jumlah zat besi yang dibutuhkan untuk memproduksi sel-sel darah merah sehingga tubuh dapat menormalkan konsentrasi hemoglobin sebagai protein pengankut oksigen (Winkjosastro, 2012). Penyebab anemia pada umumnya adalah Kuran ggizi (malnutrisi), kurang zat besi, mal absorpsi, kehilangan darah banyak seperti persalinan yang lalu, haid dan lain-lain (Kurniyati, 2021).

Anemia dalam kehamilan dapat berpengaruh buruk terutama saat kehamilan, persalinan dan nifas. Anemia juga menyebabkan peningkatan risiko perdarahan pasca persalinan. Prevalensi anemia yang tinggi berakibat negative seperti:

1) Gangguan dan hambatan pada pertumbuhan, baik sel tubuh maupun sel otak,

2) Kekurangan $\mathrm{Hb}$ dalam darah mengakibatkan kurangnya oksigen yang dibawa / ditransfer ke sel tubuh maupun ke otak. Sehingga dapat memberikan efek buruk pada ibu itu sendiri maupun pada bayi yang dilahirkan ( Manuaba, 2012 ).

Dalam menanggulangi masalah tersebut maka upaya yang dilakukan untuk mencegah terjadinya anemia dan segala dampak yang mungkin terjadi dengan melakukan pemeriksaan ante natal care secara teratur di tempat pelayanan kesehatan, banyak mengkonsumsi makanan yang banyak mengandung protein seperti daging, hati, telur, sayur- sayuran, asam folat (Vitamin C) dan konsumsi tablet fesecara teratur serta cara minum yang benar dan sesuai kondisi/kebutuhan.

\section{Kejadian Perdarahan Post Partum}

Berdasarkan hasil penelitian menunjukkan bahwa dari 29 ibu bersalin di Puskesma Lenteng Kecamatan Lenteng Kabupaten Sumenep Tahun 2020 sebagian besar yaitu sebanyak 17 ibu bersalin (59\%) mengalami perdarahan post partum.

Perdarahan pasca persalinan didefinisikan sebagai kehilangan darah $\geq 500$ $\mathrm{ml}$ setelah persalinan pervaginam atau $\geq 1000 \mathrm{ml}$ setelah seksiosesaria (Kenneth, 2009). Perdarahan post partum merupakan penyebab kematian maternal terbanyak di indonesia. Menurut Wiknjosastro, (2012) Perdarahan post partum secara fisiologis dikontrol oleh kontraksi serat-serat myometrium terutama yang berada di sekitar pembuluh darah yang mensuplai 
darah pada tempat perlengketan plasenta. Atonia uteri terjadi saat myometrium tidak dapat berkontraksi secara adekuat.

Upaya yang dapat dilakukan untuk mencegah terjadinya perdarahan post partum dan segala dampak yang mungkin terjadi tidak hanya dilakukan pada saat bersalin tetapi sejak masa kehamilan dengan melakukan pemeriksaan ante natal care secara teratur di tempat pelayanan kesehatan (minimal $4 \mathrm{x}$ selama masa kehamilan) ,bersalin di rumah sakit yang mempunyai sarana dan prasarana yang lebih lengkap atau memiliki bank darah, penerapan asuhan persalinan normal mencegah "Empat Terlalu" yaitu terlalu muda (16 tahun), terlalu tua ( $>35$ tahun) usia ibu untuk memutuskan hamil, terlalu sering melahirkan dan terlalu dekat jarak kehamilan/persalinan (Manuaba 2012 ).

\section{Hubungan Anemia Dengan Kejadian Perdarahan Post Partum}

Berdasarkan hasil tabulasi silang antara anemia dengan kejadian perdarahan post partum di Puskesmas Lenteng Kecamatan Lenteng Kabupaten Sumenep Tahun 2020 menunjukkan bahwa dari 19 ibu bersalin (100\%) yang mengalami anemia selama masa kehamilan ada sebanyak $17 \mathrm{ibu}$ bersalin $(94,5 \%)$ yang mengalami perdarahan post partum dan sebanyak 2 ibu bersalin (5,5\%) tidak mengalami perdarahan post partum. Sedangkan dari 10 ibu bersalin yang tidak mengalami anemia selama masa kehamilan seluruhnya yaitu 10 ibu bersalin (100\%) tidak ada yang mengalami perdarahan post partum.

Setelah di lakukan uji statistik menggunakan uji Chi Square didapatkan nilai probabilitynya $(p)=0,000$. Hal ini menunjukkan nilai probability (p) kurang dari $\alpha(0,000<0,05)$ maka dapat memberikan arti bahwa H1di terima yaitu ada hubungan anemia dengan kejadian perdarahan post partum di Puskesmas Lenteng Kecamatan Lenteng Kabupaten Sumenep Tahun 2020.

Menurut World Health Organization (WHO) anemia pada ibu hamil adalah kondisi dengan kadar hemoglobin ( $\mathrm{Hb})$ dalam darahnya kurang dari 11 gr\%. Anemia dapat mengurangi daya tahan tubuh ibu danjuga menyebabkan peningkatan risiko perdarahan pasca persalinan. Anemia juga menjadi salah satu faktor penyebab perdarahan postpartum, akibat dari anemia tersebut maka jumlah oksigen yang dipasok ke uterus berkurang sehingga menyebabkan ketidakmampuan uterus untuk mengadakan kontraksi sebagaimana mestinya. Pada anemia jumlah efektif sel darah merah berkurang. Hal ini mempengaruhi jumlah kadar haemoglobin dalam darah. Kurangnya kadar haemoglobin menyebabkan jumlah oksigen yang diikat dalam darah juga sedikit, sehingga mengurangi jumlah pengiriman oksigen dan cakupan nutrisi ke uterus (Proverawati, Atikah, 2011).

Pada saat ibu bersalin maka akan terjadi kontraksi uterus yang adekuat sehingga bayi lahir, apabila ibu mengalami anemia selama kehamilan maka kontraksi uterus akan berkurang hal ini diakibatkan karena kurangnya jumlah oksigen dan nutrisi pada organ uterus, apabila uterus kekurangan oksigen dan nutrisi maka sel- sel uterus akan mengalami penurunan kinerja berupa penurunan kontraksi, penurunan kontraksi inilah yang akan menyebabkan terjadinya perdarahan.

Hal ini sejalan dengan penelitian yang dilakukan oleh Rinawati Sembiring, (2010) dengan judul " Hubungan anemia dengan kejadian perdarahan post partum di RSUP H.Adam Malik Medan " yang di peroleh sebagian besar ibu bersalin yang mengalami perdarahan Post partum mempunyai riwayat anemia selama masa kehamilannya.

Namun ada 2 ibu bersalin yang mengalami anemia selama masa kehamilan tapi tidak mengalami perdarahan post partum, hal ini sangat bertentangan dengan teori yang sudah di sebutkan oleh beberapa sumber, setelah di kaji lebih lanjut ternyata kadar $\mathrm{Hb}$ ibu bersalin tersebut termasuk dalam katagori anemia ringan yaitu 10,8gr\% dan 10,9gr\%.

Berdasarkan hasil penelitian dapat di simpulkan bahwa anemia sangat berpengaruh terhadap kejadian perdarahan post partum. Dalam menanggulangi masalah tersebut maka upaya yang dapat dilakukan untuk mencegah terjadinya perdarahan post partum yang di sebabkan oleh anemia adalah dengan pemeriksaan ante natal care secara teratur di tempat pelayanan kesehatan (minimal $4 \mathrm{x}$ selama masa kehamilan), banyak mengkonsumsi makanan yang banyak mengandung protein seperti daging, hati, telur, sayur- sayuran, asam folat (Vitamin C) dan konsumsi tablet fesecara teratur serta cara minum yang benar dan sesuai kondisi/kebutuhan

\section{KESIMPULAN}

Sebagian besar ibu bersalin di Puskesmas Lenteng Kecamatan Lenteng Kabupaten 
Sumenep dari bulan Agustus - Desember Tahun 2020 mempunyai riwayat anemia selama masa kehamilannya. Dan mengalami perdarahan post partum. Sehingga ada hubungan anemia dengan kejadian perdarahan post partum di Puskesmas Lenteng.

\section{DAFTAR PUSTAKA}

Alimul , A. 2013. Riset Keperawatan. Jakarta:SalembaMedika

Alimul, A. 2011. Metode penelitian Keperawatan dan Teknil Analisis data, SalembaJakarta

Arif Mansjoer. 201. Kapita Selekta Kedokteran.Jakarta: Media Acsulapius.

Arikunto, Prof. Dr. Suharsimi. 2017. Prosedur penelitian suatu pendekatan praktik. Jakarta : PT Rineka Cipta

BKKBN 2013..Bimbingan Teknis

Kesehatan Reproduksi dan Seksualitas Yang

Komprehensif. Jakarta BKKBN

Depkes RI. 2019. Skenario Percepatann Penurunan AKI.

Emma, S. Wira Kusumah 2009..Perencanaan Menu Anemia Gizi Besi. Jakarta Tribus Agriwidya

Heriyanto, 2011, Analisis Faktot Yang Mempengaruhi Perdarahan Post Partum di RS Sardjito Yogyakarta. Tesis FK UGM:.\ Yogyakarta

Indriyani, R., \& Suprayitno, E. (2017). Hubungan Postpartum Blues Dengan Keputusan Menggunakan KB Pasca Nifas Di UPT Puskesmas Lenteng. Journal Of Health Science (Jurnal Ilmu Kesehatan), 2(2), 70-75.

Indriyani, R., Aulia, A., Andrian, M. W., \& Suprayitno, E. (2020). Pengaruh Konsumsi Sari Buah Jambu Merah dan Madu terhadap Kenaikan Nilai HB pada Ibu Hamil di Tempat Praktek Mandiri Bidan Muarofah Surabaya. Wiraraja Medika: Jurnal Kesehatan, 10(1), 36-40.

Kenneth,I. 2009. Obstetri William: Panduan ringkas,Edisi ke-21.Jakarta: EGC

Kurniyati, E. M., Setiawati, A. C., Suprayitno, E., \& Indriyani, R. (2021). SARI KACANG HIJAU DAN MADU MENINGKATKAN NILAI HEMOGLOBIN REMAJA KELAS XI: Green and Honey Bean Sari Increases Hemoglobin Value of Class XI Adolescents. Jurnal Ilmiah Kebidanan (Scientific Journal of Midwifery), 7(1), 12-18.
Manuaba, 2012, Ilmu Kebidanan, Penyakit Kandungan dan Keluarga Berencana untuk Pendidikan Bidan. Jakarta

Manuaba, I.B.G. 2012. Kapita Selekta Penatalaksanaan Rutin Obstetri Ginekologi dan Keluarga Berencana.Jakarta.

Marni dan Kukuh Rahardja. 2012. Panduan Kehamilan Dan Persalinan. Yogyakarta. Pustaka Belajar

Miswarti. 2017. Hubungan Kejadian Perdarahan Post Partum Dini dengan Paritas di RSUD Dr,M. Djamil Padang. KTI. Politeknik Kesehatan Padang

Mochtar (2005). Sinopsis Obstetri jilid 2. Jakarta. ECG

Notoatmodjo, Soekidjo 2013. Pendidikan dan Perilaku Kesehataan. Jakarta: Rineka Cipta.

Notoatmodjo. 2012. Metodelogi Penelitian Ilmu Keperawatan. Jakarta Rineka Cipta

Notoatmodjo.2013. .Metodologi Penelitian Kesehatan. Jakarta : Rineka Rineka Cipta

Nursalam. 2012. Konsep Penerapan Metodologi Penelitian Ilmu Keperawatan. Jakarta: Salemba Medika

Nursalam. 2013. Metodologi Penelitian Ilmu Keperawatan (Pendidikan Praktis).

Nursalam.2012.PendekatanPraktisMeto dologiRisetKeperawatanJakarta:JagungSeto

Pardosi,M. (2009). Analisis Faktor-Faktor yang Berhubungan dengan Perdarahan Pasca Persalinan dan Upaya Penurunannya di Wilayah Kerja Puskesmas Kota Medan Tahun 2009. Tesis. Medan: FKM USU

Proverawati Atikah. 2011..Anemia dan Anemia kehamilanl. Yokyakarta: Nuha Medika.

Saifuddin AB, dkk. 2012. Buku acuan nasional pelayanan kesehatan maternal dan neonatal. Jakarta: YayasanBinaPustaka.

Soepardan, Suryani. 2008. Konsep kebidanan. Jakarta: EGC

Tarwoto, 2017. Buku Saku Anemia Pada Ibu Hamil, Trans Info Media, Jakarta.

Varney Helen. 2008, Buku Ajar Asuhan Kebidanan. Jakarta

Wiknjosastro, H. 2012. IlmuKebidanan. Jakarta: YayasanBinaPustaka. 